\title{
Inflation accounting and control through monetary policy measures in Nigeria: Multi-regression analysis (1973-2010)
}

\author{
Akabom-Ita Asuquo, Ph.D \\ Department of Accounting \\ Faculty of Management Sciences \\ University of Calabar, Calabar \\ Cross River State - Nigeria
}

\begin{abstract}
This study was carried out to evaluate Inflation accounting and control through monetary policy measures in Nigeria from 1973 to 2010. Secondary data were used empirically to do the assessment. Aggregate data on independent variables (monetary policy measures) that affect inflation were collected and analyzed using multiple regression model and the ordinary least squares estimation techniques. From the analysis carried out, it was found that some of the variables (money supply, interest rate and exchange rate) were statistically significant, which means that the studied variable could be used to predict inflation. Furthermore, domestic credit was not statistically significant, even though it could be used as a policy variable to account for inflation. Based on these findings, it was recommended that monetary supply, interest rates and exchange rates should be the principal policy variables to be manipulated in controlling inflation in Nigeria.
\end{abstract}

\section{Background of the study}

Inflation is a serious macroeconomic problem and it is an aspect of macroeconomic instability. It can make a comparison of economic conditions at different point in time quite difficult, creates complications for economic measurement, and brings uncertainty when we try to look into the future. Inflation is a substantial and sustained increase in general price level leading to disequilibrium thus undermining the ability of money to serve as a tool for market coordination. In Nigeria, monetary policy measures are used to control inflation and other macro-economic variables in order to ensure economic stability. Monetary policy involves measures designed to regulate and control the volume, cost, availability and direction of money and credit in an economy to achieve some specific macroeconomic policy objectives (Anyanwu, and Oackhenan, 1995).

Monetary policy also refers to a combination of measures designed to regulate the value, supply and cost of money in an economy, in consonance with the expected level of economic activity (Nnanna, 2001). Nyong (2001) opined that monetary policy is concerned with changes in interest rate, money supply or other monetary aggregate. It refers to action undertaken by the monetary authorities to alter the equilibrium of the monetary market either by changing the money supply or altering the interest rate. Monetary policy affects economy either directly through aggregate demand (the monetarist) or indirectly through interest rate (Keynesian). The essence of monetary policy to an economy includes price stability, maintenance of balance of payments equilibrium, promotion of employment and output growth, and sustainable development. Monetary policy is also part of an overall economic policy that regulates the level of growth of money stock and credit in an economy as well as an adjustment policy to stimulate sustainable economic growth and development. (Adamson, 2000).

The emphasis given to price stability in the conduct of monetary policy is with a view to promoting sustainable growth and development as well as strengthening the purchasing power of the domestic currency amongst others (CBN, 2007). Consequently, the reduction in the purchasing power of the domestic currency results in domestic price fluctuation which undermines the role of money as a store of value, and frustrates investment and growth. Ojo, 2000 and Nnanna, 2001, all opined that empirical studies on inflation, growth and productivity, confirmed long term inverse relationship between inflation and growth. Therefore, for sustainable economic growth, the Central Bank of Nigeria must initiate sound monetary policy measures to fight inflation, hence ensuring price stability. Indeed, the imperative to understand inflation comes as a result of the implications of frequent price increases in the system. Some of these implications include: 
(a) Discouragement of long term planning;

(b) Reduction in investment

(c) Reduction in savings and capital accumulation;

(d) Shift in the distribution of real income and consequent misallocation of resources;

(e) Creating uncertainty and distortions in the economy.

Suffice it to say that the reduction of these inflationary implications and the maintenance of domestic price stability is a critical goal of monetary policy of the Central Bank of Nigeria. Low and stable inflation rates facilitate the attainment of the major goals of macroeconomic policy such as growth and allocation efficiency. It must be noted however, that the causes of inflation goes beyond monetary causes. In Nigeria, weatherinduced variations in food supplies have without doubt been a major non-monetary factor in the movement of the price level (Odozi, 1992). The relatively large and persistent Naira depreciation in the last few years has been a significant contributory factor owing to the global economic recession (economic meltdown) instability in the Niger Delta region, caused by Niger Delta militants and the high import dependency of the country.

It is important to note that over the years, the Central Bank of Nigeria has been operating monetary targeting regime. However, there has been a growing preference for inflation targeting in recent times. The clamour for this paradigm shift is due to changing relationship between different measures of monetary aggregates and policy targets, induced largely by financial sector liberalization and globalization. Inflation targeting is a policy directed towards inflation itself rather than any intermediate measure.

On the whole, the effectiveness of monetary policy to effectively control inflation depends on the operating economic environment, the institutional framework adopted and the choice and mix of the instruments used (Nnanna, 2001). More so, the effectiveness of monetary policy is a function of the complementarity of monetary and fiscal policies as well as the extent of coordination between them (Ebi, 2003).

Central Bank of Nigeria's effective performance of statutory function(s) is predicated upon its ability to formulate and implement monetary policy, with the overriding objective of maintaining price stability, balance of payments equilibrium, output growth and employment as well as sustainable development.

Price stability is therefore inevitable for money to perform its role as a store of value and medium of exchange; hence price volatility undermines the ability of policy makers to achieve other laudable macroeconomic objectives.

However, over the years monetary policy measures are taken to control inflation; yet there have been a consistent rise in inflation year in year out. For instance, in pre-SAP era (1980-1985), inflation was above 40 percent (hyperinflation) Odusola (2006). On an annual basis, inflation rose from 57 per cent in 1994 to 72.8 percent in 1995, dropped to 29.3 percent in 1996 and 8.5 per cent in 1997, rose to 10 percent in 1998. In 1999, it was 6.6 percent and rose consistently from 6.6 per cent in 1999 to 6.9 percent in 2000, and 18.9 percent in 2001. In 2002, dropped to 12.9 percent, rose to 14 percent in 2003 and 15 percent in 2004 (CBN, 2006).

Considering the above inflationary trend over the last ten years, it becomes pertinent to investigate why monetary policy has not been able to stabilize prices. It is in the light of the above scenario that this research intended to assess to what extent monetary policy variables have affected inflation and its control in Nigeria.

\section{Inflation and unemployment}

\section{Impact Of Inflation On Macroeconomic Variables}

Inflation and unemployment constitute two major goals of interest to economic policy makers. Both inflation and unemployment have far-reaching effects on the economy, the society and the welfare of individuals (Iyoha, Oyefusi, Oriakhi, 2003). According to Iyoha, Oyefusi, Oriakhi (2003), the performance of an economy can be seen by looking at the inflation and unemployment rates. Both rates when added, gives us a nation's "misery index," a measure of the national economic discomfort. It is therefore, imperative that policy makers strive to lower inflation and lower unemployment at the same time, but quite often, these goals conflict. The adoption of monetary and/or fiscal policy moves the economy along the short-run aggregate supply curve to a point of higher output and a higher price level. As higher output is recorded, this is followed by lower unemployment, as firms need more workers when they produce more and vice versa. This trade-off between inflation and unemployment is described as the Philips curve. 


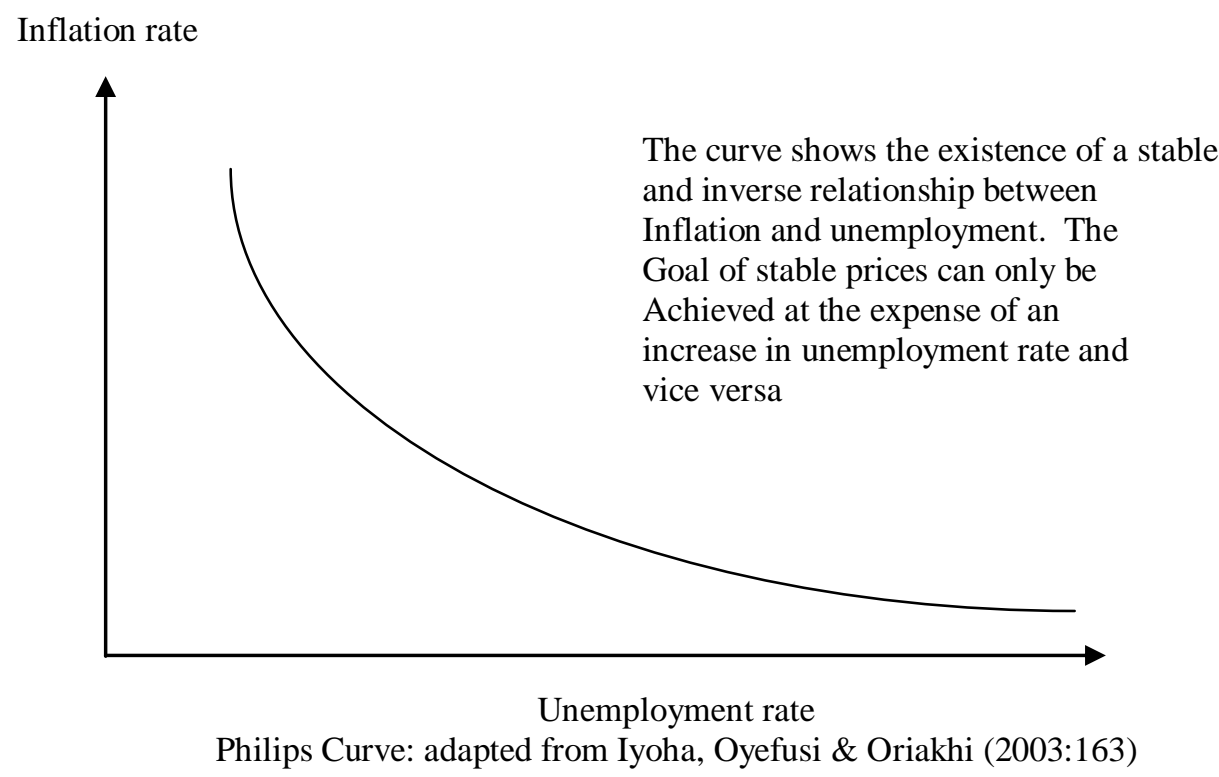

The Philips curve was subjected to empirical test using data from the United Kingdom plotted over the period 1862-1957. The result of the tests confirmed the existence of an inflation-unemployment trade-off. The discovery is strengthened by the fact that movement in the money wages could be explained by the level and changes of unemployment, an argument in favour of the Philips curve is the extension that establishes a relationship between prices and unemployment. This rests on the assumption that wages and prices move in the same direction. The strength of Philips curve is that it captures an economically reliable empirical relationship between inflation and unemployment.

Since the 1960s much of government policy has been based on the premise established by the Philips curve. However, in the 1970s, evidence began to emerge concerning the instability of the curve (Iyoha, Oyefusi, Oriakhi, 2003). The purported trade-off between inflation and unemployment was found to exist only in the short-run. In the 1980s many countries experienced conditions of inflation and rising unemployment at the same time (suggesting thus a positive relationship between the two).

Nonetheless, Philips curve does not take into account the interaction in the underlying or structural behaviour of consumers and firms in the economy, but rather captures empirical regularities between unemployment and inflation rates based purely on correlations in historical data. Perhaps, the greatest weakness of the Philips curve is its lack of theoretical underpinnings. Secondly, the trade-off that exists between trying to keep the rate (two objectives which government desire to pursue simultaneously), which has raised concern that some given level of unemployment rate, that would be consistent with some level of inflation has to be determined, if both objectives have to be pursued. (Oleka, 2006, CBN, 2007 \& Essien, 2002).

Nevertheless, controversies rage on. This is primarily because the Philips curve of the United Kingdom appears to be a special case, which remains to be validated unambiguously in other economies. This has rendered it an inconclusive guide to policy as to how inflation may be tackled, even in the highly industrialized economies. So far, issues pertaining to what rates of unemployment and inflation are to be regarded as tolerable, or what levels are to be regarded as consistent with the broad policy objective of full employment remain unresolved. Despite these shortcomings, the Philips curve is still being used as a basis for forecasting inflation (CBN, 2007).

\section{Inflation and exchange rate}

The exchange rate is the price of foreign currency in terms of the domestic currency. Like other prices in a market economy, it sends signals that affect consumption and investment decisions and, therefore, influences both the composition and value of aggregate demand and supply.

Exchange rate has a major role in monetary policy measures; its significance in monetary policy arises from its link to inflation, external competitiveness and balance of payments consideration. Exchange rate being a monetary instrument, its interaction with other monetary variables such as the money stock, interest rate and liquidity conditions is crucial to the achievement of macroeconomic stability (Folorunso and Abiola, 2000).

Friedman (1956) had argued that exchange rate instability is a manifestation of economic volatility. The determinants of exchange rate include amongst others; economic fundamentals, such as the GDP, inflation, 
balance of payments, socio-political factors, macroeconomic shocks and speculative contagion. These drivers influence exchange rate dynamics though the demand for and supply of foreign exchange which can exert or ease the pressure on the market and cause the exchange rate to depreciate or appreciate. However, a more depreciated exchange rate to increase competitiveness or to solve a balance of payments is usually done at the expense of higher inflation. (Nzekwe (2006), posits that pegging the exchange rate can lower inflation by inducing greater policy discipline and instilling greater confidence in the currency. He further averred that policy makers have long maintained that a pegged exchange rate can be an anti inflationary tool. Two reasons are typically cited. A pegged exchanged rate provides a highly visible commitment and thus raises the political costs of loose monetary and fiscal policies. To the extent that the peg is credible, there is a stronger readiness to hold domestic currency, which reduces the inflationary consequences of a given expansion in the money supply. It is imperative to note that countries with pegged exchange rates have lower rates of growth in money supply and consequently inflation.

However, the monetary theories attempt to explain changes in exchange rates in terms of changes in the demand and supply of money between two countries. According to this theory, an increase in money supply causes the exchange rate to depreciate as a result of the induced inflationary pressures (Nyong, 2005).

\section{Administration of monetary policy in Nigeria}

Monetary policy for consideration by the president is proposed by the CBN through a memorandum usually titled, monetary and credit policy proposals which is for a particular fiscal year. The memorandum, an input of all the policy departments of the CBN is coordinated by the research department. The input takes into account the views and suggestions of financial system operators, the business community, and other interested members of the public. It also considers the prevailing economic conditions, prospects and the policy objectives that appear most appropriate to pursue in the immediate future. The memorandum is initially considered by the committee of Governors, the highest management body for the day-to-day administration of the CBN. It is finally discussed, amended, if need be, and approved by the board of directors of the CBN. Thereafter, it is transmitted by the Governor of the CBN to the president for consideration and approval. The president after due consultation with other organs of government, takes a decision on which proposals to accept and announces them in the budget. It is pertinent to add here that in the current Nigerian setting, the success of monetary policy hinges crucially on the extent to which the budgetary programme of the federal government can be harmonized with the goals of monetary policy (Odozi, 1992). This is due to the crucial role of the government in the economy and for this reason the government has continued to be the largest sources of liquidity growth in the system.

However, after the budget announcement, the accepted proposals are subsequently outlined for banks and other financial institutions by the CBN, in the form of a monetary policy circular for compliance. Penalties for non-compliance with specified guidelines are also indicated in the circular.

As a monitoring device, the CBN conducts periodic and special examinations of the books of all licensed banks which are also required to submit returns on their operations to the CBN. The examinations and returns from the financial institutions as well as current economic developments enable the CBN to assess compliance with the monetary policy circular, and to determine the need for change in the circular. Routine amendments to the circular are undertaken by the CBN, while fundamental changes must be discussed with the president.

\section{Constraints of monetary policy in the management of inflation in Nigeria}

Despite efforts in the past years by the monetary authority to achieve macroeconomic and price stability in Nigeria, there have been constraints militating against the attainment of these objectives. These constraints include:

- Fiscal dominance and the concomitant large fiscal deficits averaging about 3.0 percent of GDP, having militated against the efficacy of monetary policy in Nigeria (Nanna 2001). Government fiscal operations especially the inflationary financing of large budgetary deficits and the monetization of deficits, have continued to pose serious challenges to monetary management.

- Liquidity overhang: The sources of liquidity in the economy are varied. However, the growth of credit to government predominated. Other sources include the monetization of enhanced oil export receipts, particularly in 2000; the minimum wage adjustment in 2000; and the fiscal operation of the state and local government in Nigeria. The political federalism which Nigeria practices is a serious constraint on the bank's ability to control the money supply in the economy.

- Data: the poor quality of data is a major constraint in the formulation of the monetary policy in Nigeria. The lack of high frequency and unreliable data renders econometric analysis difficult. Similarly fiscal shocks give rise to parameter uncertainly, which also undermines the setting of accurate target. It is hope 
that this problem will be ameliorated with the computerization of the financial system and the introduction of a transparent fiscal regime.

- Dualistic financial and product market: The informal sector in Nigeria account for about 30 per cent of GDP (Nnanna, 2001). The existence of the large informal credit market and exchange rate market in Nigeria has many implications for the transmission mechanism of monetary policy. For instance, a divergence between the official and parallel market exchange rate induces, in the short run, a chain of speculative activities which invariably undermine the efficiency of policy instrument.

- Inefficient payment system: the payment system is a vital link between the financial system and the real sector of the economy. The payment instrument in Nigeria is predominantly cash. The prominence of cash for transaction purpose increase the volume of currency in circulation or high-powered money, which renders monetary control difficult, if not impossible. There is a general consensus in literature that an inefficient payment system distorts the transmission mechanism of monetary policies even when the design and objectives are laudable (Nnanna, 2001).

- Political interference: Experience has shown that most often the political class interferes with the policies of the Central Bank. Example is the recent re-denomination of the naira by the Central Bank which was stopped by the government. An independent Central Bank will have the explicit mandate to formulate and implement monetary policy in other to pursue price stability and promote equilibrium in the balance of payment. This explicit mandate and independence is generally an important institutional device and framework of ensuring price stability (Curkieman, Stephen, Webb and Neyati, 1992).

\section{Research Design}

\section{Research Methodology}

The expo-facto research design was adopted in this study to obtain secondary data from records prepared after the occurrence of the research variables/events of interest.

\section{Instrumentation}

The major instruments used in collecting data for this research were the computer via surfing the internet. This was use to access the Central Bank database, mainly for those data that were not found in other documents such as CBN statistical bulletin, bullion and annual abstract from the Federal office of statistics. Suffice it to say that these data were considered to be reliable and valid for the study because of the sources from which there were obtained.

\section{Data collection procedure}

Data for this research were obtained from secondary sources, these sources include textbooks, journals, magazines, CBN bulletins, bullions, annual reviews, national dailies, annual abstract of statistics and published annual statement of accounts. More so, time series data from 1973 to 2010 were used, as information for this study came from intense library research.

\section{Model specification}

The regression model for this study was based on the monetarist theory of inflation as articulated in review of literature. The literature reviewed; also uncovered some of the determinants of inflation.

To this end, the model or function must contain variables showing their relationship. The relationship between inflation and relevant monetary variables can be expressed in functional form as given below:

$$
\mathrm{INF}=\mathrm{f}(\mathrm{MS}, \mathrm{DC}, \mathrm{INTR}, \mathrm{EXCHR})
$$

Where:

$\begin{array}{lll}\text { INF } & = & \text { Inflation rate } \\ \text { MS } & = & \text { Money supply } \\ \text { DC } & = & \text { Domestic credit } \\ \text { INTR } & = & \text { Interest rate } \\ \text { EXCHR = } & \text { Exchange rate }\end{array}$

In order to make the regression function to be in an estimation form, the function is reformulated to include the stochastic error term.

INF $=a_{0}+a_{1} L_{n} M_{s}+a_{2} L_{n} D_{c}+a_{3} L n$ INTR $+a_{4} L_{n} E X C H R+U \ldots .1$

Apriori $=\mathrm{a}_{1}, \mathrm{a}_{2}$, and $\mathrm{a}_{3}>\mathrm{O}$, $\mathrm{a} 4<0$

Where:

$\mathrm{U}=$ The stochastic error term

$\mathrm{a}_{\mathrm{o}}$ to $\mathrm{a}_{4}=$ represent the various parameter estimates measuring the impact of explanatory variables

$\mathrm{Ln}=\log$ of the variables. 


\section{Presentation of data}

Table I

\begin{tabular}{|l|l|l|l|l|l|}
\hline YEAR & INF & MS2 & DCR & INTR(R) & EXCHR \\
\hline 1973 & 13.8 & 547.9 & 351.5 & 8 & 0.714 \\
\hline 1974 & 16 & 698.4 & 502 & 10 & 0.696 \\
\hline 1975 & 3.2 & 743.7 & 619.5 & 10 & 0.658 \\
\hline 1976 & 5.4 & 985.9 & 753.5 & 10 & 0.658 \\
\hline 1977 & 13.4 & 1178.3 & 938.1 & 10 & 0.63 \\
\hline 1978 & 33.9 & 2044.1 & 1437.5 & 9 & 0.616 \\
\hline 1979 & 21.2 & 3481.8 & 2123 & 10 & 0.62 \\
\hline 1980 & 15.4 & 4047.4 & 4313.5 & 6 & 0.647 \\
\hline 1981 & 16.6 & 4785.8 & 4114.9 & 11 & 0.606 \\
\hline 1982 & 11.8 & 6146.6 & 4630.4 & 11 & 0.593 \\
\hline 1983 & 9.9 & 9226.8 & 6349.1 & 9.5 & 0.546 \\
\hline 1984 & 20.9 & 9744.8 & 8582.9 & 10 & 0.61 \\
\hline 1985 & 7.7 & 10048.8 & 10275.3 & 11.75 & 0.673 \\
\hline 1986 & 23.2 & 11282.4 & 11093.9 & 11.5 & 0.724 \\
\hline 1987 & 39.6 & 12204.1 & 11503.6 & 13 & 0.765 \\
\hline 1988 & 5.5 & 13267.8 & 12170.2 & 11.75 & 0.894 \\
\hline 1989 & 5.4 & 13105 & 15701.6 & 12 & 2.02 \\
\hline 1990 & 10.2 & 14905.9 & 17531.9 & 19.2 & 4.02 \\
\hline 1991 & 38.3 & 20052.7 & 19561.2 & 17.6 & 4.54 \\
\hline 1992 & 40.9 & 46222.9 & 22008 & 24.6 & 7.39 \\
\hline 1993 & 7.5 & 64902.7 & 26000.1 & 27.7 & 8.04 \\
\hline 1994 & 13 & 86152.5 & 31306.2 & 20.8 & 9.91 \\
\hline 1995 & 44.5 & 129085.4 & 42736.8 & 31.2 & 17.3 \\
\hline 1996 & 57.2 & 198519.1 & 65665.8 & 36.09 & 22.33 \\
\hline 1997 & 57 & 2669449 & 66127.6 & 21 & 21.89 \\
\hline 1998 & 72.8 & 318763.5 & 114883.9 & 20.79 & 21.89 \\
\hline 1999 & 29.3 & 370333.5 & 169437.1 & 20.86 & 21.89 \\
\hline 2000 & 8.5 & 429731.4 & 385560.5 & 23.32 & 21.89 \\
\hline 2001 & 10 & 525637.6 & 272895.5 & 21.34 & 21.89 \\
\hline 2002 & 6.6 & 699733.7 & 1265984 & 27.19 & 85.98 \\
\hline 2003 & 6.9 & 1036080 & 179568 & 21.55 & 102.5 \\
\hline 2004 & 18.9 & 1315869.1 & 2796112 & 21.34 & 11 \\
\hline 2005 & 12.9 & 1599494.6 & 3606229 & 30.19 & 120.5 \\
\hline 2006 & 14 & 1985192 & 4339443 & 22.88 & 128.5 \\
\hline 2007 & 15 & 2263588 & 5686669 & 20.82 & 134 \\
\hline 2008 & 17.9 & 2814856 & 7391290 & 19.49 & 130.15 \\
\hline 2009 & 8.2 & 4027902 & 9542573 & 17.41 & 122.5 \\
\hline 2010 & 5.4 & 5809827 & 15285129 & 18.36 & 117.75 \\
\hline & & & & & \\
\hline
\end{tabular}

Source: CBN Annual Reports and Statistical Bulletin-Various issues

CBN Statistical Bulletin 2010

KEY

INF

INTR

EXCHR -

- Inflation rate

- $\quad$ Interest Rate (maximum Lending rate)

DCR - $\quad$ Domestic Credit

MS2

- $\quad$ Money supply 


\section{Regression results}

\section{Dependent variable: INF Variable}

Table 2

Coefficient Std.Error t-Statistic Prob.

\begin{tabular}{lllll}
\hline INF (1) & 2.461184 & 0.548148 & 4.489999 & 0.0003 \\
INF (2) & -0.759369 & 0.185722 & -4.088745 & 0.0006 \\
LOG (MS) & 3.428067 & 3.492042 & 0.981680 & 0.3386 \\
LOG(MS (-1)) & 5.049061 & 2.185382 & -2.310379 & 0.0323 \\
LOG(MS (-2)) & 1.512108 & 1.922986 & 0.786333 & 0.4414 \\
LOG (DC) & 17.51908 & 11.35697 & 2.542583 & 0.0004 \\
LOG (DC(-1)) & -21.36066 & 13.13740 & -1.625943 & 0.1204 \\
LOG (DC(-2)) & 3.455424 & 11.20513 & 0.308379 & 0.7611 \\
D(INTR) & -0.545084 & 0.590469 & -0.923137 & 0.3675 \\
D(INTR(-1)) & 2640583 & 0.756673 & -3.489730 & 0.0025 \\
D(INTR(-1)) & -0.429456 & 0.681468 & 0.630193 & 0.5361 \\
D(EXCHR) & -0.956598 & 0.326104 & -2.933409 & 0.0085 \\
D(EXCHR(-1)) & 0.073226 & 0.307122 & 0.238427 & 0.8141 \\
D(EXCHR(-2)) & 0.261943 & 0.446071 & 0.587222 & 0.5640 \\
ECM(-1) & -0.112123 & 0.603925 & -3.497327 & 0.0024 \\
C & & & & 0.3624 \\
\hline \hline
\end{tabular}

R-squared

Adjusted R-squared

F-statistic

Durbin-Watson stat
$0.780730 *$
$0.607622 *$
4.510077
2.133321

\section{Best fit model}

The result of the over-parameterized model reveals that most of the coefficients $(2.461184$ (INF(-1), 3.428067 LOG (MS), 5.04961 LOG (MS (-1)), 1.1512108 LOG (MS (-2)), 17.51908 LOG (DC), -21.36066 LOG DC (-1), 3.455424 LOG (DG (-2)), 2.640583 D (INT (-1)), -0.956598 D (EXCHR) of the variables have the right sign and conform with economic theoretical expectation.

However the concern of this study was in the parsimonious model/result where insignificant variables were eliminated to allow for a more interpretable dynamic result (see table 3).

\section{Parsimonious model/result}

\section{Table 3}

\begin{tabular}{|c|c|c|c|c|}
\hline $\begin{array}{l}\text { Dependent variable: INF } \\
\text { Variable }\end{array}$ & Coefficient & Std.Error & t-Statistic & Prob. \\
\hline INF (1) & 2.327873 & 0.337660 & $6.894123 * *$ & 0.0000 \\
\hline INF (2) & -0.569720 & 0.139847 & $-4.073891 * *$ & 0.0003 \\
\hline LOG(MS (-1)) & 2.284365 & 1.337137 & $-2.708399 * *$ & 0.0006 \\
\hline LOG (DC) & 1.850458 & 1.136818 & $1.627753 *$ & 0.1148 \\
\hline D(INTR (-1)) & 2.141840 & 0.479882 & $-4.463265 * *$ & 0.0001 \\
\hline $\mathrm{D}(\mathrm{EXCHR})$ & -0.580753 & 0.191534 & $-3.032117 * *$ & 0.0052 \\
\hline ECM (-1) & -0.882380 & 0.362648 & $-5.190650 * *$ & 0.0000 \\
\hline $\mathrm{C}$ & 9.412965 & 8.799184 & $-1.069754^{*}$ & 0.2939 \\
\hline R-squared & $0.705674 *$ & & & \\
\hline Adjusted R-squared & $0.632093^{*}$ & & & \\
\hline F-statistic & 9.590383 & & & \\
\hline Durbin-Watson stat & 2.348506 & & & \\
\hline
\end{tabular}

Best-fit model 


\section{Test of Hypotheses}

In view of the research hypotheses formulated in this study, it is necessary to finalize the analyses by testing the hypotheses.

Hypothesis one

From the analysis of the results, last year money supply variable (Ms (-1) is statistically significant at five per cent level. This implies that money supply has significant impact on inflation in Nigeria. Therefore, our null hypothesis of no significant relationship between money supply and inflation is rejected and the alternative hypothesis accepted.

\section{Hypothesis two}

From the analysis, last year's interest rate (INTR (-1) has a significant impact on the current level of inflation in Nigeria. Therefore, the null hypothesis is rejected and the alternative hypothesis accepted. This implies that there is a significant relationship between change in interest rate and inflation in Nigeria.

\section{Hypothesis three}

From the analysis of the estimated result, domestic credit (DC) has a positive relationship with inflation but its impact is not significant at five per cent level. In the light of the above, the null hypothesis is accepted and the alternative hypothesis rejected. Thus, there is no significant relationship between domestic credit and inflation in Nigeria.

\section{Hypothesis four}

From the analysis, exchange rate has a negative relationship with inflation in Nigeria and is significant at five percent level. Thus, the null hypothesis is rejected and the alternative hypothesis is accepted. The implication is that there is a significant relationship between exchange rate and inflation in Nigeria.

\section{Discussion of findings}

From the results of our hypotheses as stated above, money supply has a significant impact on inflation in Nigeria. That means that the effectiveness of monetary policy is dependent on the ability of the monetary authority to use its monetary policy instruments to fine tune money supply in order to stabilize prices. The monetary authority should ensure that money supply is just sufficient to stimulate growth. Secondly, our result shows that interest rate has a significant impact on the current level of inflation in Nigeria. This also suggests that to effectively control inflation, the monetary authority should as a matter of priority monitor interest rate to ensure that it is relatively stable. This will boost investment and subsequently reduce inflation.

Thirdly, our analysis shows that domestic credit (DC) has a positive relationship with inflation, but not significant at five percent level. The implication is that domestic credit does not impact or influence inflation significantly, but the result must be interpreted with caution, especially given that it is consistent with economic theory, this implies that it can still be manipulated as a monetary policy variable to control inflation.

Lastly, exchange rate was found to have a significant relationship with inflation. Therefore, the effectiveness of monetary policy on the control of inflation is also dependent on the part of the monetary authority to adjust and readjust the exchange rate in order to control inflation and maintain sustainable growth in the economy.

\section{Summary}

This study was carried out to assess the effectiveness of monetary policy measures on inflation control in Nigeria. Monetary policy is simply a combination of measures designed to regulate the value, supply and cost of money in an economy in consonance with the expected level of economic activity. It is concerned with changes in interest rate, money supply and other monetary aggregates. In order to validate our work, theoretical and empirical literature relevant to our study were reviewed. At the empirical level, ordinary least squares (OLS) econometric methodology was adopted to examine some of the selected monetary policy variables on inflation.

However, this study was motivated by the fact that inflation is one of the target variables that had consistently been a yardstick for measuring the effectiveness and the performance of the monetary authority. In the light of the above, it is pertinent that the monetary authority uses its instrument to adequately control some of our chosen variables such as money supply, domestic credit, interest rate and exchange rate; hence our findings showed that money supply, interest rate and exchange rate are statistically significant and impact sufficiently on inflation. Only domestic credit was not found to be significant but it can still be used as a policy variable to control inflation. 


\section{Conclusion}

It is a well known fact that over the years, monetary policy has not made the desired impact on price stability in Nigeria. Nonetheless, a number of reasons have been advanced for why the performance of monetary policy over the years has been abysmal. These include lack of sufficient control of the financial institutions, political interference and the global economic recession caused by over-exposure of banks to the capital market. More so, the inability of the monetary authority to use monetary instrument such as open market operations, reserve requirements, etcetera with accuracy to deal with the problem of inflation in the economy.

However, based on this study, money supply, interest rate and exchange rate are the monetary policy variables that can be appropriately manipulated to control inflation in Nigeria. In the light of this, it is suggested that the Central Bank of Nigeria's guideline for banks should be strictly followed and the Central Bank should be given absolute control devoid of political interference so that the monetary policy can be well coordinated to achieve the desired macroeconomic objectives.

\section{Recommendations}

In the light of our findings as discussed above and the conclusion reached, the following recommendations are made:

1. More emphasis should be placed on money supply, hence it has much influence in controlling inflationary pressure in Nigeria. It is imperative on the side of government not to arbitrarily change money supply, since the growth rate of money induce inflation. Government should ensure that money supply is just sufficient to stimulate non-inflationary sustainable economic growth. Moreso, private individual should be encouraged to imbibe banking habits. Excess money outside the banking system not only reduces the lending strength of the banks but have negative effective on the economy.

2. The monetary authority should as a matter of priority monitor interest rate to ensure that it is relatively stable. This would boost investment and by extension reduce inflation. On the other hand, the monetary authority can come up with policies that will adequately find tune interest rate to achieve non-inflationary growth of the economy.

3. The monetary authority should design monetary policy instruments contingent to our socio-political environment, and not necessarily copy-paste from other developed economy, hence monetary policy is recognized to be a potent tool in controlling inflation in Nigeria.

4. It is equally realized that effective and successful implementation of monetary policy depends on the health of the banking institutions. For the above policy to work there is a need for a sound banking system. This can only be achieved if the monetary authority provides adequate framework for banks to operate. This would in no small way, enhance the efficacy of monetary policy as it is through the banking system that monetary policy works efficiently.

5. There should also be proper coordination between monetary and fiscal policy. Proper and efficient coordination between monetary and fiscal policy enhance discipline in government spending; hence the large proportion of budget deficit financed subsequently by banks result in inflationary situation.

6. Finally, though several researches have been conducted on the subject matter, we recommend further study on especially the instruments and strategies that can be designed to suit our socio-political and economic environment to curb inflation.

[1] Adamson Y. K. (2000). "Structural Disequilibrium and Inflation in Nigeria: A Theoretical and Empirical Analysis." Center for Economic Research on Africa. New Jersey 07043; Montclair State University, Upper Montclair.

[2] Anyanwu, J. C. and Oaikhenan, H. E (1995). Modern Macroeconomics: Theory and Applications in Nigeria. Onitsha: Joanee Educational Publishers.

[3] CBN Briefs, Research Department, Series No. 92 (03).

[4] CBN Statistical Bulletin, 2006, 20 (5).

[5] Cukierman, A; Steven, B., Webbs, S. B. and Neyati, B. (1992). "Measuring the Independence of Central Bank and its Effect on Policy Outcomes." The World Bank Economic Review. 6, (3).

[6] Ebi, E. (2003). Central Bank of Nigeria Third Annual Monetary Policy Conference, Issues in Fiscal Management; Implication for Monetary Policy in Nigeria.

[7] Essien, E. A. (2002). "Identifying the Trend of Core Inflation in Nigeria." Central Bank of Nigeria Economic and Financial Review. 40, (2).

[8] Folorunso, B. A. and Abiola, A. G. (2000). "The Long-Run Determinants of Inflation in Nigeria (1970) - 1998.” Nigerian Journal of Economic and Social Studies, 42, (1).

[9] Friedman, M. (1956). Studies in the Quantity Theory of Money. Chicago: University of Chicago Press.

[10] Iyoha, A. A., Oyefusi, S.A. and Oriakhi, D. E. (2003). An Introduction to Modern Macroeconomic. Benin: Mindex Publishing.

[11] Nnanna, O. J. (2001). Monetary Policy Framework in Africa: The Nigeria Experience. www.cenbank.com.

[12] Nyong, M. O. (2001). Public Policy, Public Sector Economics and Management in Nigeria. Calabar: University of Calabar Press.

[13] Nyong, M. O. (2008). Unpublished Lecture Note on Recent Advances in Econometric Methodology (Time Series). Root Test and Co-Integration Analysis. University of Calabar. 
[14] Nzekwe, G. (2006). Exchange Rate Stability and Poverty Reduction in Nigeria. CBN Bullion. 30 (3).

[15] Odozi, V. A. (1992). Current Monetary and Banking Policies in Nigeria and the Prospects in the Third republic. Central Bank of Nigeria Economic and Financial Review. 30, (3).

[16] Odusola, A. (2006). Economic Rate Management. CBN Bullion 30, (3).

[17] Odusola, A. (2006). Sustainable Economic Growth through Inflation Targeting in Nigeria. Inflation Targeting in Nigeria, CBN, Abuja 2006.

[18] Ojo, M. O. (2000). Fiscal and Monetary Policy during Structural Adjustment in Nigeria. Proceeding of a Senior National Policy Workshop. Uyo: Abbnny Educational Publishers.

[19] Olekah, J. K. A. (2006): Inflation Targeting in Practice: Country Experience and Lesson for Nigeria. CBN Proceedings of the Fifteenth Annual Conference of Research and Statistics Office.

[20] The Dynamics of Inflation in Nigeria: CBN, Research and statistics Department, August 2007. 